\title{
COMPARISON OF DIRECT COSTS OF PERCUTANEOUS FULL-ENDOSCOPIC INTERLAMINAR LUMBAR DISCECTOMY AND MICRODISCECTOMY: RESULTS FROM TURKEY
}

\author{
Ülkün Ünlü ÜNSAL' ${ }^{1}$, Salim ŞENTÜRK²
}

\author{
'Department of Neurosurgery, Manisa City Hospital, Manisa, Turkey \\ ${ }^{2}$ Department of Neurosurgery, Memorial Bahcelievler Hospital, Istanbul, Turkey
}

○) | English | https://doi.org/10.18071/isz.74.0197 | www.elitmed.hu

Background and purpose - Microdiscectomy (MD) is a standard technique for the surgical treatment of lumbar disc herniation (LDH). Uniportal percutaneous full-endoscopic interlaminar lumbar discectomy (PELD) is another surgical option that has become popular owing to reports of shorter hospitalization and earlier functional recovery. There are very few articles analyzing the total costs of these two techniques. The purpose of this study was to compare total hospital costs among microdiscectomy (MD) and uniportal percutaneous full-endoscopic interlaminar lumbar discectomy (PELD). Methods - Forty patients aged between 22-70 years who underwent PELD or MD with different anesthesia techniques were divided into four groups: (i) PELD-local anesthesia (PELD-Local) $(n=10)$, (ii) PELD-general anesthesia (PELD-General) ( $n=10)$, (iii) MD-spinal anesthesia (MDSpinal) $(n=10)$, (iv) MD-general anesthesia (MD-General) $(n=10)$. Health care costs were defined as the sum of direct costs. Data were then analyzed based on anesthetic modality to produce a direct cost evaluation. Direct costs were compared statistically between MD and PELD groups. Results - The sum of total costs was $\$ 1,249.50$ in the PELD-Local group, $\$ 1,741.50$ in the PELD-General group, $\$ 2,015.60$ in the MD-Spinal group, and $\$ 2,348.70$ in the MD-General group. The sum of total costs was higher in the MD-Spinal and MD-General groups than in the PELDLocal and PELD-General groups. The costs of surgical operation, surgical equipment, anesthesia (anesthetist's costs), hospital stay, anesthetic drugs and materials, laboratory workup, nursing care, and postoperative medication differed significantly among the two main groups (PELDMD) $(p<0.01)$.

Conclusion - This study demonstrated that PELD is less costly than MD.

Keywords: direct cost, endoscopic discectomy, microdiscectomy

\author{
A PERCUTAN ENDOSZKÓPOS INTERLAMINÁRIS \\ LUMBALIS DISCECTOMIA ÉS A MICRODISCECTOMIA \\ DIREKT KÖLTSÉGEINEK ÖSSZEHASONLIITÁSA: \\ TÖRÖK EREDMÉNYEK \\ Ünsal ÜÜ, MD; Şentürk S, Assos. Prof. MD \\ Ideggyogy Sz 2021;74(5-6):197-205.
}

Háttér és cél - A microdiscectomia (MD) a lumbalis porckorongsérv mútéti kezelésének standard technikája. Az egy munkacsatornás percutan endoszkópos interlamináris lumbalis discectomia (PELD) egy másik mútéti lehetőség, ami a rövidebb kórházi ápolási idő szükségessége és a gyorsabb funkcionális gyógyulás miatt egyre népszerúbbé válik. Nagyon kevés tanulmány elemzi e két technika költségeit. Jelen tanulmány célja az MD és a PELD összes kórházi költségének összehasonlítása.

Módszerek - Negyven 22 és 70 éves kor közötti, PELD vagy MD módszerrel és különböző aneszteziológiai technikával operált beteget osztottunk négy csoportba: 1. PELD + helyi érzéstelenítés (PELD-Local) ( $n=10), 2$. PELD + általános érzéstelenítés (PELD-General) $(n=10), 3 . M D+$ spinalis érzéstelenítés (MD-Spinal) ( $n=10), 4$. MD + általános érzéstelenítés (MD-General) $(n=10)$. Az egészségügyi költségeket a direkt költés összegeként definiáltuk. A költségek direkt összehasonlíthatósága érdekében az adatokat az érzéstelenítés módja szerint elemeztük. A direkt költségeket az MDés a PELD-csoportok között hasonlítottuk össze.

Eredmények - A PELD-Local-csoportban az összes költség összege 1249,5 \$, a PELD-General-csoportban 1741,5 \$, az MD-Spinal-csoportban 2015,6 \$, az MD-General-csoportban 2348,7 \$ volt. Az összes költség összege magasabb volt az MD-Spinal- és MD-General-csoportokban, mint a PELD-Local- és PELD-General-csoportokban. A mútét, a sebészi eszközök, az anesztézia (az aneszteziológus díja), a kórházi tartózkodás, az érzéstelenítés során használt gyógyszerek és anyagok, a laboratóriumi vizsgálatok, az ápolás és a posztoperatív gyógyszerelés költsége szignifikáns mértékben eltért a négy csoport között $(p<0,01)$. Következtetés - Vizsgálatunk igazolta, hogy a PELD kevésbé költséges, mint az MD.

Kulcsszavak: direkt költség, endoszkópos discectomia, microdiscectomia

Correspondent: Ülkün Ünlü ÜNSAL, MD, Manisa City Hospital, Department of Neurosurgery. Manisa, Turkey. Phone number: 055587533 96. E-mail: ulkununlu@hotmail.com https://orcid.org/0000-0001-5194-3138

Érkezett: 2021. március 2. Elfogadva: 2021. május 4. 
$\mathrm{L}$ ow-back pain is a common health problem with an estimated total cost of over $\$ 100$ billion in the United States per year ${ }^{1}$. Lumbar disc herniation is commonly seen in patients with a low-back pain. Additionally, sciatica has been reported in 1.2-43\% of patients with low-back pain. Microdiscectomy (MD) remains the gold standard in surgical treatment of lumbar disc herniation ${ }^{2}$.

Endoscopes have been used since the early 1980s to inspect the intervertebral space after completed open surgery ${ }^{3}$. The use of endoscopy in spinal surgery is increasing every day in line with the developments in minimally invasive techniques. In recent times different endoscopic discectomy techniques were described. Major advantages of endoscopic surgery include shorter hospital stay, lower intraoperative blood loss, less postoperative pain, lower complication rates, earlier functional recovery, early return to normal life, better cosmetic results, and reduced socioeconomic $\operatorname{loss}^{3-7}$. Due to these advantages, the interest in spinal surgery is increasing day by day.

Full-endoscopic spine surgery is considered an adequate and safe alternative to microsurgical procedures, mainly due to its cost-effectiveness associated with shorter working time, rapid rehabilitation, low postoperative care costs, reduced anatomic trauma, and simplified revision procedures ${ }^{8}$.

In line with these developments, endoscopic discectomy emerged as an alternative to open discectomy within the last 25 years, and has been used for various spinal diseases, predominantly lumbar disc herniation $^{8-15}$. Additionally, its applicability under local anesthesia has also been reported in recent years ${ }^{16}$. Although there have been numerous clinical studies comparing MD and endoscopic discectomy $^{8,17-20}$, to our knowledge, there are very few articles analyzing the costs of these two techniques.
Moreover, there are still questions regarding the cost of uniportal percutaneous full-endoscopic lumbar discectomy (PELD) ${ }^{21,22}$. The aim of this study was to compare costs of MD and PELD performed in a class A private hospital in Turkey.

\section{Materials and methods}

\section{STUDY DESIGN}

In this retrospective chart review, the authors reviewed electronic medical records of all surgical cases meeting the inclusion criteria, and then consulted these records with the hospital revenue cycle teams to obtain outcomes and cost data. Data were then analyzed based on anesthetic modality to produce a direct cost evaluation. All the surgeries were performed in a private hospital that had no contract with the social security institution (SGK) in Turkey, where treatment costs were covered by patients themselves or through private health insurances. All the treatment costs were calculated based on the diagnosis and treatment costs determined by the hospital for each surgical procedure, regardless of the fees invoiced to private health insurances or patients.

The study included a total of 40 patients aged 2270 years who underwent PELD or MD due to a low back and/or leg pain that did not benefit from conservative treatment for at least six weeks and were detected with a motor deficit and an extruded or sequestered disc fragment between January 2017 and December 2019. Patients were divided into four groups: (i) PELDlocal anesthesia (PELD-Local) $(n=10)$, (ii) PELDgeneral anesthesia (PELD-General) $(n=10)$, (iii) MDspinal anesthesia (MD-Spinal) $(n=10)$, (iv) MD-general anesthesia (MD-General) $(n=10)$ (Table 1).

Table 1. Demographic and clinical characteristics

\begin{tabular}{|c|c|c|c|c|c|}
\hline & \multicolumn{2}{|c|}{ PELD } & \multicolumn{2}{|c|}{ MD } & \multirow[t]{2}{*}{$p$} \\
\hline & Local & General & Spinal & General & \\
\hline $\begin{array}{l}\text { Number of } \\
\text { patients }\end{array}$ & 10 & 10 & 10 & 10 & \\
\hline Gender M/F & $6 / 4$ & $7 / 3$ & $6 / 4$ & $5 / 5$ & ns \\
\hline Age & $47.6(29-65)$ & $44.5(27-64)$ & $48.2(24-70)$ & $46.9(22-69)$ & ns \\
\hline $\begin{array}{l}\text { Level of } \\
\text { surgery }\end{array}$ & & & & & \\
\hline L2-L3 & 1 (10\%) & $2(20 \%)$ & 0 & 2 (20\%) & \\
\hline L3-L4 & $5(50 \%)$ & $3(30 \%)$ & $1(10 \%)$ & $1(10 \%)$ & \\
\hline L4-L5 & $4(40 \%)$ & $4(40 \%)$ & $5(50 \%)$ & 3 (30\%) & \\
\hline L5-S1 & 0 & 1 (10\%) & $4(40 \%)$ & $4(40 \%)$ & \\
\hline
\end{tabular}

PELD: uniportal percutaneous full-endoscopic lumbar discectomy, MD: microdiscectomy, ns: no significant 
Patients with a history of lumbar disc surgery at the same level, multilevel lumbar disc herniation, spinal stenosis and spondylitis, cauda equina syndrome, and patients with complicated lumbar disc herniation that could indirectly affect the treatment costs were excluded from the study. The type of anesthesia was determined based on patient's age, preference, and comorbidities. Preoperative X-ray and lumbar magnetic resonance imaging (MRI) were performed in all patients after clinical and sociodemographic evaluation. All costs were calculated in detail for each transaction by converting Turkish lira to USD (\$) based on the exchange rate valid on the date of the surgery. Average treatment costs as well as direct costs were calculated for each group.

\section{DIRECT COSTS}

These costs included surgical operation (surgeonnurse-allied healthcare personnel), surgical equipment (for PELD: vicrly, drape, tincture of iodine, sterile gloves, Omnistrip, bistoury; for MD: microscope cover, Surgicel, Monocryl, surgical pad, bonewax, cautery plate, cautery, tincture of iodine, sponge), diagnostic tests (Lumbar X-ray and MRI included), anesthesia (anesthetist's costs), hospital stay (a 6-hour fee charged in case of patients discharged on the same day, and a fullday fee charged in case of patients staying for one day or more, including meals), anesthetic drugs and materials, laboratory workup (including postoperative hemoglobin measurement in MD patients), nursing care, and postoperative medication (a single-dose analgesia fee charged in case of patients staying up to six hours, and a single-dose analgesia fee and a two-dose antibiotic fee charged for each day in case of patients staying for one day or more).

\section{SURGICAL INTERVENTIONS}

All surgeries were conducted by the same surgical team with more than 10-year experience in spinal surgery and more than 8-year experience in endoscopic spinal surgery. Uniportal percutaneous fullendoscopic interlaminar lumbar discectomy (PELD) and microdiscectomy (MD) have been described previously ${ }^{7,23}$.

\section{STATISTICAL ANALYSIS}

Statistical analysis was performed using SPSS for Windows version 21.0 (Armonk, NY: IBM Corp.). Descriptives were expressed as mean, median, minimum, maximum, and quartiles. Considering the sample size, binary comparisons were performed using Mann-Whitney U test, and multiple comparisons were performed using Kruskal-Wallis and pairwise comparison tests. A $p$ value of $<0.05$ was considered significant.

\section{Results}

\section{PATIENT POPULATION}

The study included 40 patients that underwent lumbar discectomy, with 10 patients in each group. Mean age was 47.6 (range, 29-65) years in the PELD-Local group, 44.5 (range, 27-64) years in the PELD-General group, 48.2 (range, 24-70) years in the MD-Spinal group, and 46.9 (range, 22-69) years in the MD-General group. No significant difference was observed among the groups with regard to age and gender (Table 1).

Mean operative time was 35 (range, 25-48) min. in the PELD-Local group, 33 (range, 22-45) min. in the PELD-General group, 48 (range, 40-66) min. in the MD-Spinal group, and 45 (range, 35-60) min. in the MD-General group. Mean hospital stay was 0.47 (range, 0.25-1) day in the PELD-Local group, 1.1 (range, 1-2) days in the PELD-General group, 1.3 (range, 1-2) day in the MD-Spinal group, and 1.4 (range, 1-3) days in the MD-General group. Significant difference was found among the four groups with regard to operative time and hospital stay ( $p<0.05$ for both) (Table 2 ).

Table 2. Operative time and hospital stay

\begin{tabular}{|c|c|c|c|c|c|}
\hline & \multicolumn{2}{|c|}{ PELD } & \multicolumn{2}{|c|}{ MD } & \multirow[t]{2}{*}{$\mathrm{p}$} \\
\hline & Local & General & Spinal & General & \\
\hline Operative time (min) & $35(25-48)$ & $33(22-45)$ & $48(40-66)$ & $45(35-60)$ & $<0.01$ \\
\hline Hospital stay (days) & $0.4(0.25-1)$ & $1.1(1-2)$ & $1.3(1-2)$ & $1.4(1-3)$ & $<0.01$ \\
\hline
\end{tabular}

PELD: uniportal percutaneous full-endoscopic lumbar discectomy, MD: microdiscectomy 
Table 3. Direct costs

\begin{tabular}{|llllll|}
\hline & PELD-Local & PELD-General & MD-Spinal & MD-General & $\begin{array}{l}\text { P } \\
\text { (PELD-MD) }\end{array}$ \\
\hline $\begin{array}{l}\text { Operation } \\
\text { (Surgeon's costs) }\end{array}$ & $\$ 814.6$ & $\$ 814.6$ & $\$ 1,037$ & 1,037 & $<0.01$ \\
$\begin{array}{l}\text { Surgical Equipment } \\
\text { Radiology }\end{array}$ & $\$ 56.9$ & $\$ 56.9$ & $\$ 133.2$ & $\$ 133.2$ & $<0.01$ \\
$\begin{array}{l}\text { Including MRG } \\
\text { and X-ray) }\end{array}$ & $\$ 55.8$ & $\$ 55.8$ & $\$ 55.8$ & $\$ 55.8$ & 1 \\
$\begin{array}{l}\text { Anesthesia } \\
\text { (Anesthetist's costs) }\end{array}$ & $\$ 38$ & $\$ 352.7$ & $\$ 288.8$ & $\$ 352.7$ & $<0.01$ \\
$\begin{array}{l}\text { Hospital stay } \\
\text { (including meals) }\end{array}$ & $\$ 129.5$ & $\$ 191.2$ & $\$ 270.9$ & $\$ 462.2$ & $<0.01$ \\
$\begin{array}{l}\text { Anesthetic drugs } \\
\text { Laboratory workup }\end{array}$ & $\$ 4.18$ & $\$ 111.7$ & $\$ 55.8$ & $\$ 11.7$ & $<0.01$ \\
$\begin{array}{l}\text { Nursing Care } \\
\text { Postoperative }\end{array}$ & $\$ 14$ & $\$ 128.6$ & $\$ 132.6$ & $\$ 132.6$ & $<0.01$ \\
$\begin{array}{l}\text { medication } \\
\text { Total Costs }\end{array}$ & $\$ 8$ & $\$ 18$ & $\$ 24.5$ & $\$ 43.5$ & $<0.01$ \\
\hline
\end{tabular}

\section{CLINICAL OUTCOMES}

In the PELD-Local group, 7 (70\%) patients were discharged within a mean period of 6 (range, 4-12) hours after surgery on the same day and $3(30 \%)$ patients were discharged one day after surgery.

In the PELD-General group, 9 (90\%) patients were discharged one day and $1(10 \%)$ patient was discharged two days after surgery.

In the MD-Spinal group, $7(70 \%)$ patients were discharged one day and $3(30 \%)$ patients were discharged two days after surgery.

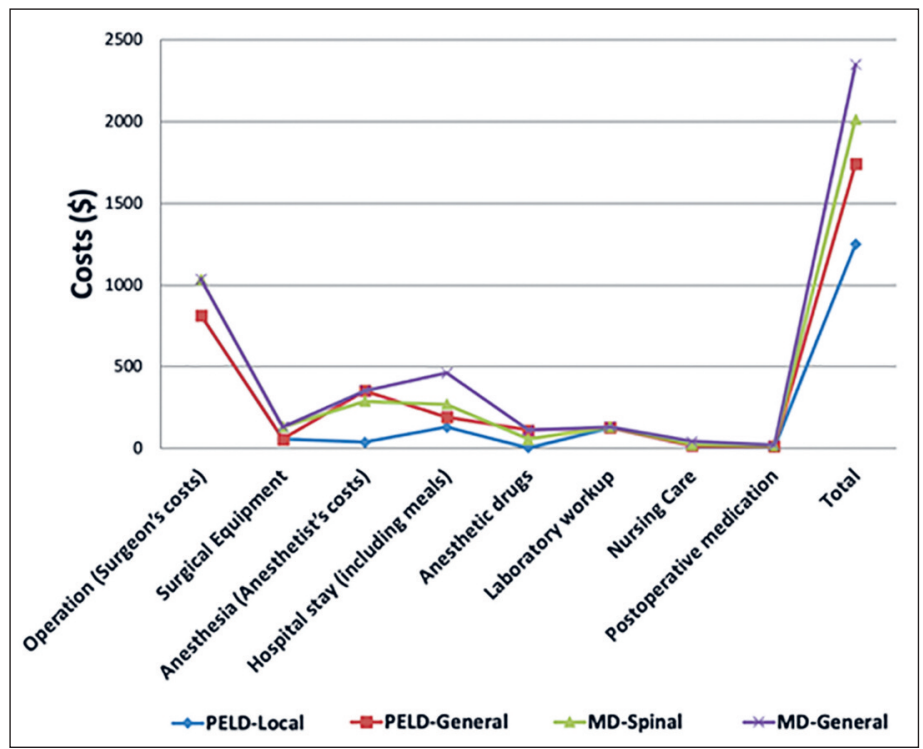

Figure 1. Line chart shows the comparison of each direct cost between groups
In the MD-General group, 7 (70\%) patients were discharged one day, 2 (20\%) patients were discharged two days and $1(10 \%)$ patient was discharged three days after surgery.

\section{TOTAL COST ANALYSIS}

The sum of total costs was $\$ 1,249.50$ in the PELDLocal group, $\$ 1,741.50$ in the PELD-General group, $\$ 2,015.60$ in the MD-Spinal group, and $\$ 2,348.70$ in the MD-General group (Table 3).

The sum of direct healthcare costs was higher in the MD-Spinal and MD-General groups than in the PELD-Local and PELD-General groups. Additionally, the costs of operation, surgical equipment, anesthesia (anesthetist's costs), hospital stay, anesthetic drugs and materials, laboratory workup, nursing care, and postoperative medication differed significantly among the two main groups (PELD-MD) $(p<0.01$; Table 3, Figure 1).

As for the costs of radiological workup, no significant difference was found among the four groups since the costs of lumbar MRI and lumbar $\mathrm{X}$-ray were the same for all patients.

Significant difference was found between PELD groups and MD groups with regard to total costs $(p<0.01$; Table 4). In binary comparisons, although no significant difference was found between PELD-General and PELD-Local group in terms of total costs; the sum of direct healthcare costs was higher in the PELD-General group than in the PELD-Local. In other binary comparisons, significant differences were found in terms of total costs (Table 5). 
Table 4. Binary comparisons (direct costs)

\begin{tabular}{|llll|}
\hline & & $\mathrm{N}$ & $\mathrm{P}$ \\
\hline Operation (Surgeon's costs) & PELD & 20 & $<0.01$ \\
& MD & 20 & \\
Surgical Equipment & Total & 40 & \\
& PELD & 20 & $<0.01$ \\
Anesthesia (Anesthetist's costs) & MD & 20 & \\
& Total & 40 & \\
& PELD & 20 & $<0.01$ \\
Hospital stay (including meals) & MD & 20 & \\
& Total & 40 & \\
Anesthetic drugs & PELD & 20 & $<0.01$ \\
& MD & 20 & \\
\multirow{5}{*}{ Laboratory workup } & Total & 40 & \\
& PELD & 20 & $<0.01$ \\
Nursing care & MD & 20 & \\
& Total & 40 & \\
Postoperative medication & PELD & 20 & $<0.01$ \\
& MD & 20 & \\
Total & Total & 40 & \\
& PELD & 20 & $<0.01$ \\
& MD & 20 & \\
& Total & 40 & \\
& PELD & 20 & $<0.01$ \\
& MD & 20 & \\
& Total & 40 & \\
& PELD & 20 & $<0.01$ \\
& MD & 20 & \\
& Total & 40 & \\
\hline
\end{tabular}

PELD: uniportal percutaneous full-endoscopic lumbar discectomy, $M D$ : microdiscectomy

\section{Discussion}

Cost-effectiveness has become a major concern in treatment decisions due to the limits on health expenditures. More and more studies also suggest that surgery can also lead to substantial cost-effectiveness ${ }^{11}$. For these reasons, treatment costs are an important component of decision-making processes and thus spinal surgeons face the challenge of treating patients with affordable methods. Approximately 500,000 lumbar discectomy surgeries are performed annually in the USA ${ }^{12}$. According to the Spine Patient Outcomes Research Trial (SPORT) for lumbar disc herniation, the cost of surgery per "Quality-adjusted Life Year" (QALY) $(\$ 34,355)$ is lower than that of nonoperative treatment $(\$ 69,403)$ although surgical costs $(\$ 27,273)$ are higher than non-surgical costs $(\$ 13,135)^{24}$. The present study compared the healthcare costs of PELD and MD performed with different anesthetic techniques in surgical treatment of lumbar disc herniation.

In our study, direct healthcare costs varied depending on the surgical and anesthetic technique used for treatment, length of hospital stay, diagnostic tests, and the drugs and medical equipment used in the procedure. Moreover, the radiological costs (lumbar MRI and X-ray) were considered the same in all four groups.

\section{PELD-LOCAL GROUP}

This group had the lowest total cost $(\$ 1,249.50)$ among all four procedures, which could be attributed to the lower costs of drugs, anesthesia (including anesthetist's costs and the costs of monitoring and patient care only), hospital stay (short-term hospitalization), nursing care (short-term nursing care) and postoperative medication (less medication) in this group due to administration of a single injection of local anesthesia (lidocaine $1 \%$ ). However, the remaining costs (surgical operation, surgical equipment, and laboratory workup) were the same as those of PELD-General group since these costs were not affected by anesthesia.

\section{PELD-GENERAL GROUP}

This group had the second lowest total cost $(\$ 1,741.50)$ among all groups. Although no significant difference was found between PELD-General and PELD-Local groups, a significant difference was found between PELD-General and both MD groups (MD-Spinal and MD-General), which could be explained by the fact that the costs of operation, surgical equipment, and laboratory workup were not affected by anesthesia. Choi et al. ${ }^{25}$ compared hospital costs among patients that underwent microdiscectomy with different endoscopic techniques and reported that endoscopic discectomy was less costly than microdiscectomy. In our study, the cost of anesthetic drugs in the PELD-General group was similar to that of MD-General group, while it was higher than those of MD-Spinal and PELD-Local group. Moreover, the cost of anesthesia (cost of anesthetist) in the PELD-General group was higher than that of PELD-Local and MD-Spinal groups, while it was similar to that of MD-General group. These findings could be attributed to the increase in costs caused by the additional costs of equipment, gas, and intravenous anesthetics used for general anesthesia, as shown by Vural et al. ${ }^{26}$. On the other hand, in our study, the costs of hospital stay, nursing care, and postoperative medication were higher in 
Table 5. Binary comparisons

\begin{tabular}{|c|c|c|c|c|c|c|c|}
\hline & & 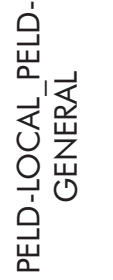 & 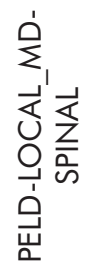 & 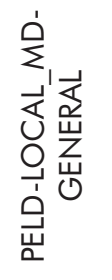 & 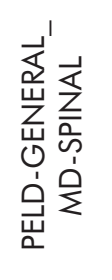 & 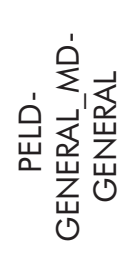 & 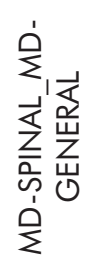 \\
\hline Operation & $\begin{array}{l}\text { PELD-LOCAL } \\
\text { PELD-GENERAL } \\
\text { MD-SPINAL } \\
\text { MD-GENERAL } \\
\text { Total }\end{array}$ & ns & $<0.01$ & $<0.01$ & $<0.01$ & $<0.01$ & ns \\
\hline Surgical Equipment & $\begin{array}{l}\text { PELD-LOCAL } \\
\text { PELD-GENERAL } \\
\text { MD-SPINAL } \\
\text { MD-GENERAL } \\
\text { Total }\end{array}$ & ns & $<0.01$ & $<0.01$ & $<0.05$ & $<0.05$ & ns \\
\hline $\begin{array}{l}\text { Anesthesia } \\
\text { (Anesthetist's costs) }\end{array}$ & $\begin{array}{l}\text { PELD-LOCAL } \\
\text { PELD-GENERAL } \\
\text { MD-SPINAL } \\
\text { MD-GENERAL } \\
\text { Total }\end{array}$ & $<0.01$ & $<0.01$ & $<0.01$ & $<0.05$ & ns & $<0.05$ \\
\hline $\begin{array}{l}\text { Hospital stay } \\
\text { (including meals) }\end{array}$ & $\begin{array}{l}\text { PELD-LOCAL } \\
\text { PELD-GENERAL } \\
\text { MD-SPINAL } \\
\text { MD-GENERAL } \\
\text { Total }\end{array}$ & $<0.01$ & $<0.01$ & $<0.01$ & $<0.01$ & $<0.01$ & $<0.01$ \\
\hline Anesthetic drugs & $\begin{array}{l}\text { PELD- LOCAL } \\
\text { PELD-GENERAL } \\
\text { MD-SPINAL } \\
\text { MD-GENERAL } \\
\text { Total }\end{array}$ & $<0.01$ & $<0.01$ & $<0.01$ & $<0.05$ & ns & $<0.05$ \\
\hline Laboratory workup & $\begin{array}{l}\text { PELD-LOCAL } \\
\text { PELD-GENERAL } \\
\text { MD-SPINAL } \\
\text { MD-GENERAL } \\
\text { Total }\end{array}$ & $\mathrm{ns}$ & $<0.01$ & $<0.01$ & $<0.01$ & $<0.01$ & ns \\
\hline Nursing care & $\begin{array}{l}\text { PELD-LOCAL } \\
\text { PELD-GENERAL } \\
\text { MD- SPINAL } \\
\text { MD-GENERAL } \\
\text { Total }\end{array}$ & ns & $<0.05$ & $<0.01$ & $<0.01$ & $<0.01$ & $<0.01$ \\
\hline $\begin{array}{l}\text { Postoperative } \\
\text { medication }\end{array}$ & $\begin{array}{l}\text { PELD-LOCAL } \\
\text { PELD-GENERAL } \\
\text { MD-SPINAL } \\
\text { MD- GENERAL } \\
\text { Total }\end{array}$ & ns & $<0.01$ & $<0.01$ & ns & $<0.01$ & ns \\
\hline Total costs & $\begin{array}{l}\text { PELD- LOCAL } \\
\text { PELD-GENERAL } \\
\text { MD-SPINAL } \\
\text { MD-GENERAL } \\
\text { Total }\end{array}$ & ns & $<0.01$ & $<0.01$ & $<0.01$ & $<0.01$ & $<0.01$ \\
\hline
\end{tabular}

PELD: uniportal percutaneous full-endoscopic lumbar discectomy, MD: microdiscectomy, ns: no significant

\section{2 Ünsal: Direct costs of PELD and MD}

Az alábbi dokumentumot magáncélra töltötték le az eLitMed.hu webportálról. A dokumentum felhasználása a szerzői jog szabályozása alá esik. 
the PELD-General group than in the PELD-Local group and were lower than those of MD-Spinal and MD-General groups, which could be ascribed to the shorter hospitalization or the discharge of most patients on the day of surgery in the PELD-Local group and to the longer hospitalization in MD groups (particularly in the MD-General group).

\section{MD-SPINAL GROUP}

Both MD-Spinal and MD-General groups had the highest costs of operation, surgical equipment, and laboratory workup, which could be attributed to the use of more equipment in microdiscectomy and to the more invasive nature of microdiscectomy when compared to that of endoscopic discectomy ${ }^{23}$. Additionally, the costs of anesthesia (costs of anesthetist) and anesthetic drugs were higher in this group than in the PELD-Local group, while they were lower than those of PELD-General and MDGeneral groups, which could be explained by the higher cost of general anesthesia compared to spinal anesthesia ${ }^{26}$. On the other hand, this group had the second-highest costs of hospital stay, nursing care, and postoperative medication following the MDGeneral group, mainly due to prolonged hospitalization. Previous studies indicated that endoscopic discectomy leads to less postoperative pain and shorter hospital stay due to less muscle damage ${ }^{17,23,27,28}$. Accordingly, the present study confirmed the advantages of endoscopic discectomy reported in the literature.

\section{MD-GENERAL GROUP}

This procedure had the highest costs in all healthcare costs among all four groups. Additionally, a significant difference was observed between this procedure and all other three procedures groups with regard to direct healthcare costs. We consider that the higher direct healthcare costs in microdiscectomy compared to endoscopic discectomy could be primarily attributed to longer hospitalization and the use of general anesthesia (as compared to PELD-Local group).

PELD requires a smaller skin incision and leads to less iatrogenic paraspinal muscle damage due to the utilization of the muscle resection technique compared to MD. In our study, additional postoperative medication was used in both MD groups due to the increased need of analgesics in the postoperative period, which could be attributed to the use of different surgical approaches (removal of ligamentum flavum and partial laminectomy during posterior decompression in MD groups, leading to increased muscle damage and postoperative incisional pain) with different anesthetic techniques. Studies have shown that the differences in surgical approaches and anesthetic techniques affect healthcare costs and postoperative pain control. Moreover, the studies have also indicated that the differences in anesthetic techniques can increase total costs in line with the requirement of postoperative care and prolonged hospital stay ${ }^{26,29}$. Choi et al. ${ }^{23}$ showed that PELD provides better perioperative outcomes compared to MD in terms of hospital stay, operative time, blood loss, muscle damage, and postoperative incisional pain. Based on the findings of our study, we consider that patients undergoing endoscopic discectomy can return to work earlier compared to patients undergoing microdiscectomy.

Studies conducted in Turkey and other countries have shown that the costs of spinal anesthesia in lumbar disc surgery are lower than those of general anesthesia, mainly due to the equipment, medications, and complication rates in general anesthesia ${ }^{26}$. Additionally, PELD groups have been shown to cause lower total costs. In particular, PELD-Local group has been shown to have the lowest costs, mainly due to its applicability with local anesthe$\mathrm{sia}^{16}$. As is commonly known, the hospitalization, anesthesia-related complications, and postoperative care costs may increase depending on the anesthetic technique. Of note, the anesthetic technique used in MD-General group leads to longer hospitalization, thereby resulting in higher direct $\operatorname{costs}^{26}$. A previous retrospective study compared endoscopic discectomy and microdiscectomy and reported that endoscopic discectomy was a viable alternative to microdiscectomy due to its low costs ${ }^{25}$. In a 2017 study, Debono et al. ${ }^{30}$ reported that reducing the length of hospital stay after lumbar discectomy will not decrease the quality of patient care.

Choi et al. ${ }^{25}$ compared cost-effectiveness of transforaminal endoscopic discectomy, interlaminar endoscopic discectomy, unilateral biportal endoscopic discectomy, and microdiscectomy and indicated that endoscopic discectomy was more cost-effective than microdiscectomy, although no significant difference was found among endoscopic techniques.

The present clinical study showed that PELD is less costly than microdiscectomy, which was consistent with the literature data ${ }^{8,17-19,27}$.

\section{LIMITATIONS}

First, this was a retrospective study with associated inherent limitations. Secondly, although patients with similar ages and genders were included in the 
study, the small sample size and hence the higher error rate were considered as a weakness of the study. Finally, direct effects of surgical complications were not evaluated in the study. Further randomized, prospective studies with larger patient series are needed to substantiate our findings.

\section{Conclusion}

Uniportal percutaneous full-endoscopic lumbar discectomy (PELD) was found to be less costly than microdiscectomy (MD). Additionally, a significant difference was found between PELD groups (PELD-Local anesthesia and PELD-General anesthesia) and MD groups (MD-Spinal anesthesia and MD-General anesthesia) with regard to total costs. Although no significant difference was found between PELD-Local anesthesia and PELD-General anesthesia, PELD-Local anesthesia was found to be less costly and more advantageous than PELDGeneral anesthesia.

\section{DISCLOSURE STATEMENT}

No potential conflict of interest was reported by the authors.

\section{REFERENCES}

1. Katz JN. Lumbar disc disorders and low-back pain: Socioeconomic factors and consequences. J Bone Jt Surg - Ser A 2006;88:21-4. https://doi.org/10.2106/JBJS.E.01273

2. Apostolides PJ, Jacobowitz R. Lumbar discectomy microdiscectomy: "the gold standard". Clin Neurosurg 1996;43: 228-38.

3. Forst $R$, Hausmann B. Nucleoscopy - a New examination technique. Arch Orthop Trauma Surg 1983;101:219-21. https://doi.org/10.1007/BF00436774

4. Kambin P, Sampson S. Posterolateral percutaneous suction-excision of herniated lumbar intervertebral discs. Report of interim results. Clin Orthop Relat Res 1986;37-43.

5. Soliman HM. Irrigation endoscopic decompressive laminotomy. A new endoscopic approach for spinal stenosis decompression. Spine J 2015;15:2282-9. https://doi.org/110.1016/j.spinee.2015.07.009

6. Eum JH, Heo DH, Son SK, et al. Percutaneous biportal endoscopic decompression for lumbar spinal stenosis: A technical note and preliminary clinical results. J Neurosurg Spine 2016;24:602-7. https://doi.org/10.3171/2015.7.SPINE15304

7. Ruetten S, Komp M, Godolias G. A new full-endoscopic technique for the interlaminar operation of lumbar disc herniations using $6 \mathrm{~mm}$ endoscopes: prospective 2-year results of 331 patients. Minim Invasive Neurosurg 2006;49:80-7. https://doi.org/10.1055/s-2006-932172.

8. Ruetten $S$, Komp M, Merk $H$, et al. Full-endoscopic interlaminar and transforaminal lumbar discectomy versus conventional microsurgical technique: A prospective, randomized, controlled study. Spine (Phila Pa 1976) 2008;33:931-9. https://doi.org/10.1097/BSD.0b013e318175ddb4

9. Pan Z, Ha Y, Yi S, et al. Efficacy of transforaminal endoscopic spine system (TESSYS) technique in treating lumbar disc herniation. Med Sci Monit 2016;22:530-9. https://doi.org/10.12659/msm.894870

10. Şentürk $S$, Ünsal ÜÜ. Percutaneous full-endoscopic removal of lumbar intradural extramedullary tumor via translaminar approach. World Neurosurg 2019;125:146-9. https://doi.org/10.1016/j.wneu.2019.01.206

11. Gray DT, Deyo RA, Kreuter W, et al. Population-based trends in volumes and rates of ambulatory lumbar spine surgery. Spine (Phila Pa 1976) 2006;31:1957-63. https://doi.org/10.1097/01.brs.0000229148.63418.c1
12. DeAntoni DJ, Claro ML, Poehling GG, et al. Translaminar lumbar epidural endoscopy: technique and clinical results. J South Orthop Assoc 1998;7:6-12.

13. Choi G, Pophale CS, Patel B, et al. Endoscopic spine surgery. J Korean Neurosurg Soc 2017;60:485-97. https://doi.org/110.3340/jkns.2017.0203.004

14. Şentürk $S$, Ünsal $\ddot{U} \ddot{U}$. Percutaneous Endoscopic Interlaminar Decompression of Hypervascular Spinal Metastases. World Neurosurg 2020;134:182-6. https://doi.org/10.1016/j.wneu.2019.10.175

15. Choi KC, Kim JS, Park CK. Percutaneous endoscopic lumbar discectomy as an alternative to open lumbar microdiscectomy for large lumbar disc herniation. Pain Physician 2016;19:E291-300. https://doi.org/10.1186/s12891-017-1697-8

16. Yeung A, Gore S. Endoscopic foraminal decompression for failed back surgery syndrome under local anesthesia. Int J Spine Surg 2014;8:22. https://doi.org/10.14444/1022

17. Liu X, Yuan S, Tian Y, et al. Comparison of percutaneous endoscopic transforaminal discectomy, microendoscopic discectomy, and microdiscectomy for symptomatic lumbar disc herniation: Minimum 2-year follow-up results. J Neurosurg Spine 2018;28:317-25. https://doi.org/10.3171/2017.6.SPINE172

18. Mayer HM, Brock M. Percutaneous endoscopic discectomy: Surgical technique and preliminary results compared to microsurgical discectomy. J Neurosurg 1993;78:216-25. https://doi.org/10.3171/jns.1993.78.2.0216

19. Hermantin F, Peters $T$, Quartararo L, et al. A prospective, randomized study comparing the results of open discectomy with those of video-assisted arthroscopic microdiscectomy. J Bone Jt Surg 1999;81:958-65. https://doi.org/10.2106/00004623-199907000-00008

20. Pan L, Zhang $P$, Yin $Q$. Comparison of tissue damages caused by endoscopic lumbar discectomy and traditional lumbar discectomy: A randomised controlled trial. Int J Surg 2014;12:534-7. https://doi.org/10.1016/j.ijsu.2014.02.015

21. Kamper SJ, Ostelo RWJG, Rubinstein SM, et al. Minimally invasive surgery for lumbar disc herniation: A systematic review and meta-analysis. Eur Spine J 2014;23:1021-43. https://doi.org/10.1007/s00586-013-3161-2

22. Gibson JNA, Subramanian AS, Scott CEH. A randomised 
controlled trial of transforaminal endoscopic discectomy vs microdiscectomy. Eur Spine J 2017;26:847-56.

https://doi.org/10.1007/s00586-016-4885-6

23. Choi KC, Shim HK, Hwang JS, et al. Comparison of surgical invasiveness between microdiscectomy and 3 different endoscopic discectomy techniques for lumbar disc herniation. World Neurosurg 2018;116:e750-8.

https://doi.org/10.1016/j.wneu.2018.05.085

24. Tosteson ANA, Skinner JS, Tosteson TD, et al. The cost effectiveness of surgical versus nonoperative treatment for lumbar disc herniation over two years: Evidence from the Spine Patient Outcomes Research Trial (SPORT). Spine (Phila Pa 1976) 2008;33:2108-15. https://doi.org/10.1097/brs.0b013e318182e390

25. Choi KC, Shim HK, Kim JS, et al. Cost-effectiveness of microdiscectomy versus endoscopic discectomy for lumbar disc herniation. Spine J 2019;19:1162-9. https://doi.org/10.1016/j.spinee.2019.02.003

26. Vural C, Yorukoglu D. Comparison of patient satisfaction and cost in spinal and general anesthesia for lumbar disc surgery. Turk Neurosurg 2014;24:380-4. https://doi.org/10.5137/1019-5149.JTN.8575-13.0
27. Choi G, Lee S, Bhanot A, et al. Percutaneous endoscopic discectomy for extraforaminal lumbar disc herniations: extraforaminal targeted fragmentectomy technique using working channel endoscope. Emerg Tech Spine Surg 2007;32:E93-9.

https://doi.org/10.1097/01.brs.0000252093.31632.54

28. Chen Z, Zhang L, Dong J, et al. Percutaneous transforaminal endoscopic discectomy compared with microendoscopic discectomy for lumbar disc herniation: 1-year results of an ongoing randomized controlled trial. J Neurosurg Spine 2018;28:300-10. https://doi.org/10.3171/2017.7.SPINE161434

29. Schuster M, Gottschalk A, Berger J, et al. A Retrospective Comparison of Costs for Regional and General Anesthesia Techniques. Anesth Analg 2005;100:786-94, table of contents.

https://doi.org/10.1213/01.ANE.0000148685.73336.70

30. Debono B, Sabatier P, Garnault V, et al. Outpatient lumbar microdiscectomy in France: From an economic imperative to a clinical standard - An observational study of 201 cases. World Neurosurg 2017;106:891-7. https://doi.org/10.1016/j.wneu.2017.07.065 